Journal of Elemantary School (JOES)

Volume 1 Nomor 1, Juni 2018

e-ISSN : 2615-1448

p-ISSN : 2620-7338

DOI : https://doi.org/10.31539/joes.v1i1.218

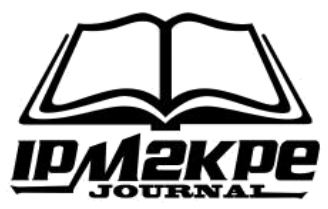

\title{
IMPLEMENTASI PENDEKATAN FLOOR TIME UNTUK MENGATASI ANAK LAMBAT BICARA USIA 3-4 TAHUN
}

\author{
Inna Hamida Zusfindhana \\ IKIP PGRI Jember \\ naahamida@gmail.com
}

\begin{abstract}
ABSTRAK
Penelitian ini untuk mengetahui implementasi pendekatan floor time dalam mengatasi anak yang mengalami keterlambatan bicara diusia 3-4 tahun. Pendekatan floor time merupakan salah satu cara terapi yang digunakan untuk mengatasi keterlambatan bicara. Tujuan dari penelitian ini untuk meningkatan perkembangan bicara anak usia 3-4 tahun. Metode yang digunakan dalam penelitian ini adalah metode kualitatif deskriptif menggunakan observasi dan wawancara untuk menggali data anak dengan keterlambatan bicara. Subjek penelitian yaitu anak lambat bicara usia 3-4 tahun yang berjumlah satu orang. Hasil penelitian menunjukkan bahwa kemampuan anak berada dalam tahapan keempat yaitu komunikasi kompleks, dimana anak mulai menunjukkan fase merabam atau lalling. Simpulan dalam penelitian ini membuktikkan bahwa dengan pendekatan floor time bisa membantu anak usia 3-4 tahun dalam meningkatkan perkembangan bicaranya.
\end{abstract}

Kata Kunci: Pendekatan Floor Time, Lambat Bicara, Usia 3-4 Tahun

\section{ABSTRACT}

This study examines the implementation of the floor time approach in dealing with children who experience speech delays at 3-4 years old. The floor time approach is one of the therapeutic methods used to overcome speech delays. The purpose of this study is to improve the speech development of children aged 3-4 years. The method used in this research is descriptive qualitative method using observation and interviews to explore children's data with speech delay. Research subjects are children who are slow to talk at 3-4 years old, amounting to one person. The results showed that the ability of children is in the fourth stage, namely complex communication, where children begin to show the phase of incarnation or lalling. The conclusions in this study prove that the floor time approach can help children aged 3-4 years in improving speech development.

Keywords : Floortime, Peech Delay, Age 3-4 Years 


\section{PENDAHULUAN}

Perkembangan bahasa dan bicara merupakan salah satu hal terpenting dalam perkembangan anak. Pada masa lima tahun pertama yang disebut dengan usia keemasan merupakan masa emas bagi perkembangan anak. Anak pada usia tersebut mempunyai potensi yang sangat besar untuk mengoptimalkan segala aspek perkembangannya, termasuk perkembangan keterampilan berbahasa dan berbicara (Hurlock, 2002).

Keterlambatan berbicara dapat mempengaruhi kondisi psikis anak sehingga mempengaruhi perilaku sosial anak. Dampak lain dari keterlambatan ini adalah tugas sekolah tertinggal, sehingga prestasi yang didapatkan anak tidak sesuai dengan standar yang telah ditentukan (Algazali, 2011). Pada usia pra sekolah biasanya anak mengalami masa peka, dimana anak mulai sensitif untuk menerima berbagai upaya pengembangan seluruh potensi. Oleh sebab itu dibutuhkan kondisi dan rangsangan yang sesuai dengan kebutuhan anak agar pertumbuhan dan perkembangan anak dapat tercapai secara optimal termasuk berkaitan dengan fungsi perkembangan bahasa dan bicaranya.

Keterampilan berbahasa dan berbicara ini sangat diperlukan untuk mendukung keberhasilan suatu kelompok agar apat mengutarakan pendapat mereka masing-masing serta dapat medengarkan pendapat dari orang lain (Astuti, 2013). Keterampilan berbahasa dan berbicara merupakan modal yang penting agar dapat menjalankan interaksi sosial yang baik meskipun keterampilan ini tidak begitu saja dimiliki oleh anak.

Hasil studi pendahuluan yang dilakukan di Laboratorium PLB IKIP PGRI Jember, diperoleh data tentang anak dengan keterlambatan berbicara. Dampak dari keterlambatan berbicara dapat diketahui anak belum bisa babbling maupun lalling. Anak hanya mampu tersenyum, tertawa dan menangis ketika menunjukkann keinginannya.Keterlambatan bicara mengakibatkan anak tidak mampu mengontrol emosinya karena ia tidak bisa mengungkapkan keinginannya, untuk mengungkapkan keinginannya dengan menangis sambil memukulkan kepala ke lantai.

Keterlambatan berbicara dapat diminimalisir melalui penanganan bicara dengan pendekatan floor time. Dr. Greenspan (2006) menyatakan bahwa: "Floor time, a systematic way of working with a child to help him climb the developmental ladder, ......" Floor time, suatu cara sistematis bekerja dengan anak untuk membantunya melalui tahapan perkembangan, dengan harapan dapat membentuk emosi yang sehat, sosial dan intelektual.

Tujuan dari penelitian ini adalah memperoleh gambaran mengenai masalah keterlambatan bicara dan meningkatkan kemampuan bicara anak usia 3-4 tahun. Sedangkan fokus dari penelitian ini adalah implementasi pendekatan floor time untuk mengatasi anak lambat bicara usia 3-4 tahun.

Untuk memahami perkembangan emosi pada diri seorang anak, Greenspan (2006) mengemukakan enam tahapan perkembangan emosi yang harus dilalui 
oleh anak. Keenam tahapan perkembangan emosi tersebut adalah: Tahapan 1, pada tahapan ini perkembangan emosi anak mampu menerima dan mengolah rangsang dari lingkungan. Bayi akan belajar mengenai cara menyeimbangkan pertumbuhan kesadaran sensori, membangun keterampilan intelektual, emosi dan sosial yang kompleks. Tahapan 2 : Keakraban - keintiman. Pada tahapan ini orang tua mempunyai peranan penting yaitu membangun keakraban dengan bayi. Selain itu, mengajarkan bayi tentang cinta dan kehangatan serta kegembiraan dalam menjalin hubungan dengan orang lain. Penguasaan tahapan ini akan mempererat keterampilan bahasa, kognitif dan gerak yang akan memberikan dasar untuk kapasitas bergerak, berpikir dan bicaranya di kemudian hari. Tahapan 3: Komunikasi dua arah.

Kemampuan anak dalam memahami komunikasi dua arah. Bentuk komunikasi tidak berupa verbal tetapi bisa ditunjukkan dengan respon atau gesture. Anak mulai bisa menentukan pilihan atau berinisiatif, misalnya anak menunjukkan emosi dengan memeluk, menggandeng atau tersenyum ketika diajak berbicara. Tahapan 4: Menetapkan komunikasi kompleks. Pada tahapan ini anak sudah menguasai dasar komunikasi dua arah, dia dapat membuka dan menutup sejumlah lingkaran dengan cepat dan kompleksitas mereka juga tumbuh, dapat merangkai gerakan kedalam respon yang rumit. Dia mulai menyertakan keinginan-keinginannya dalam bertindak tidak hanya sekedar mengikuti perintah orang tua. Anak mulai menunjukkan rasa ingin tahu yang asertif, menunjukkan ekspresi wajah, dan menunjukkan vokalisasi. Tahapan 5 : Ide Emosional. Pada tahapan ini anak mampu menciptakan ide, mengenal simbol termasuk bahasa yang melibatkan emosi. Kemampuan menciptakan ide ini awalnya berkembang dalam bermain pura-pura, yang memberikan banyak kesempatan untuk bereksperimen dengan perasaan, keinginan dan harapan.

Melalui menciptakan ide dalam bermain dan penggunaan kata-kata, anak belajar bahwa ada simbol untuk benda. Setiap simbol adalah ide, abstraksi dari benda konkret, tindakan atau emosi yang berhubungan dengan anak. Akhirnya anak mampu memanipulasi ide, menggunakannya untuk memenuhi kebutuhannya, dan meningkatkan tingkat komunikasi dan kesadaran lebih tinggi. Tahapan 6 : Berfikir emosional. Pada tahap ini anak merangkai bagian-bagian ini ke dalam suatu urutan logis dan sesuai dengan realita. Pada tahap ini anak dapat mengekspresikan rentang emosinya yang luas dalam bermain, dapat meramalkan beberapa perasaannya dan mulai melihat bahwa perasaannya dan perilakunya berpengaruh pada yang lain.

Sedangkan perkembangan bahasa anak sendiri menurut Santrock (2002) dibagi ke dalam tahapan sebagai berikut:Tahapan pertama yaitu penyuaraan refleks, seluruh aktifitas bayi yang baru lahir hinggga umur tiga minggu masih bersifat refleks, benar-benar tidak disadari, tanpa kehendak, tidak meminta atau menuntut apapun, dan bukan sedang menanggapi rangsangan, misalnya tangisan dan suaranya. Setelah umur empat minggu barulah tangisan atau suaranya mulai 
berbeda. Hal ini bukan berarti bayi sudah bisa membedakan setiapa rangsangan yang datang kepadanya tetapi masih tetap merupakan refleks. Tahapan kedua, yaitu tahap Babling yang terjadi saat bayi berumur 6-7 minggu. Pada masa ini bayi senang mengulang-ulang bunyi yang dibuatnya. Bunyi yang dihasilkan mulai bervariasi, pada minggu-minggu selanjutnya mulai terdengar bunyi-bunyi konsonan seperti $\mathrm{p}, \mathrm{b}, \mathrm{g}$ dan konsonan sengau (nasal) seperti $\mathrm{n}$. Bunyi-bunyi itu sering dikombinasikan dengan vokal, sehingga terdengar "pa pa pa pa", ba ba ba" dan "en en en".

Tahapan ketiga, yaitu tahap Lalling disebut juga tahap mengoceh atau jargon, umumnya dimulai saat bayi berumur 6-8 bulan. Tahap lalling ini hampir sama dengan tahap babling, perbedaannya terletak pada bentuk ocehan yang dihasilkan. Pada tahap lalling, ocehan sudah merupakan perpaduan beberapa konsonan dan vokal, contoh mam, mam, mam dan gub,gub,gub. Selain itu tahap lalling ini bukan lagi merupakan refleks, melainkan sudah merupakan gerakan yang disadari dan terkoordinasi. Bayi sudah memiliki feedback auditory atau kemampuan menanggapi apa yang didengar. Bayi juga sedang berlatih dengan sengaja untuk mengucapkan kata-kata. Tahapan keempat, yaitu tahap Ekolalia yang terjadi pada usia 9-10 bulan, pada tahap ini anak cenderung mengulang atau meniru suku kata yang diucapkan oleh orang lain tanpa mengubahnya. Upaya meniru juga disertai dengan penggunaan gestures atau isyarat gerakan tangan. Penggulangan kata belum disertai dengan pemahaman makna. Tahap kelima yaitu tahap True Speech, tahap ini merupakan tahap perkembangan bahasa terakhir. Tahap ini sering juga disebut sebagai tahap bicara benar atau first word atau kata pertama, umumnya terjadi saat anak berusia 9-10 bulan.

\section{METODE PENELITIAN}

Metode yang digunakan dalam penelitian ini menggunakan metode deskriptif dengan pendekatan kualitatif. Metode deskriptif bertujuan untuk mengungkap data-data di lapangan yang bersifat aktual mengenai kondisi objektif anak dalam meminimalisir keterlambatan bicara pada anak. Dalam menggali data mengenai kondisi objektif anak, menggunakan aspek-aspek yang terdapat dalam perkembangan motorik anak.

Data yang sudah terkumpul tersebut dianalisis kemudian dijadikan sebagai dasar dalam merumuskan program intervensi dini melalui pendekatan floor time untuk anak dengan lambat bicara Adapun subjek penelitian ini adalah anak usia 3-4 tahun yang berjumlah satu orang. Teknik penelitian yang digunakan yaitu observasi, wawancara, dan audiovisual atau dokumentasi.Observasi dilakukan untuk melihat dan mencatat perkembangan bicara anak. Sedangkan wawancara dilakukan pada orang tua anak dengan menggunakan wawancara terstruktur yang didalamnya menyajikan pertanyaan-pertanyaan secara sistematis yang sesuai dengan tujuan penelitian. Dokumentasi atau audiovisual yang terdiri dari gambar atau suara yang dikumpulkan oleh peneliti untuk membantu memahami merekam 
data yang digunakan. Waktu yang digunakan dalam pelaksanaan penelitian ini selama 60 menit selama 12 kali pertemuan dalam satu bulan.

Teknik analisis data dalam penelitian menggunakan tiga langkah, menurut Milles dan Huberrman yaitu reduksi data, display data, dan verifikasi data. Sedangkan pengujian kredibilitas data diperlukan untuk pengecekkan data yang dilaporkan dengan data yang ditemui di lapangan. (Creswell, 2012).

Langkah awal dalam menganalisis data yaitu dengan melakukan reduksi data. Mereduksi data berarti merangkum, memilih hal-hal yang pokok, memfokuskan pada hal-hal yang penting. Penyajian data merupakan sekumpulan informasi tersusun yang memberi kemungkinan adanya penarikan kesimpulan dan pengambilan tindakan. Langkah selanjutnya yaitu membuat rangkuman temuan penelitian berdasarkan pada aspek-aspek yang diteliti. Melalui display data, maka data akan terorganisasi, tersusun dalam pola hubungan, sehingga dapat memudahkan memahami gambaran keseluruan dari aspek-aspek yang diteliti. Kegiatan selanjutnya yaitu verifikasi data dengan cara mempelajari kembali data-data yang terkumpul dan menarik kesimpulan sehingga mendapatkan temuan baru.

\section{HASIL PENELITIAN}

Implementasi pendekatan floor time untuk anak lambat belajar menunjukkan hasil bahwa perkemangan bicara AR sampai pada tahapan komunikasi kompleks dan memasuki fase lalling. Adapum tahapan-tahapan yang dilakukan adalah: Tahapan 1 yaitu mengatur diri dan minat terhadap lingkungan. Tahapan ini AR dikenalkan pada lingkungan sekitarnya, hal ini juga dilakukan untuk menemukan minat AR. Tahapan 2 yaitu keakraban - keintiman.Tahap ini AR mulai dilatih dasar-dasar terapi wicara yaitu melalui proses pernafasan, makan, dan minum. Setelah dilakukan terapi dasar makan dan minum maupun pemijatan AR mulai merespon ketika namanya dipanggil dan menanggapi dengan senyuman. Menanggapi uluran tangan, celoteh. AR menunjukkan emosi apabila dia tidak di respon atau ditanggapi sedikitnya 60 detik. Tahapan 3 yaitu komunikasi dua arah. AR mulai menanggapi isyarat dengan gerak-isyarat yang bertujuan misalnya meraih uluran tangan, membalas celoteh atau tatapan mata. AR mulai menunjukkan emosi seperti menjulurkan tangan meminta untuk digendong, membalas ketika dipeluk. Tahapan 4 yaitu menetapkan komunikasi kompleks. Dalam tahapan ini AR semakin jelas dalam menujukkan emosi dan komunikasinya. Ketika mama menjemput AR, ia berteriak-teriak dan tertawa riang sambil mengulurkan tangan minta digendong. Ketika menginginkan sesuatu ia mulai menggandeng tangan peneliti dan mengarahkan pada benda yang diminta. 


\section{PEMBAHASAN}

Menurut Santrock (2002) tahap Babling adalah tahapan yang terjadi pada saat bayi berumur 6-7 minggu. Pada masa ini bayi senang mengulang-ulang bunyi yang dibuatnya. Bunyi yang dihasilkan mulai bervariasi, pada mingguminggu selanjutnya mulai terdengar bunyi-bunyi konsonan seperti $\mathrm{p}, \mathrm{b}, \mathrm{g}$ dan konsonan sengau (nasal) seperti n. Bunyi-bunyi itu sering dikombinasikan dengan vokal, sehingga terdengar "pa pa pa pa", ba ba ba" dan "en en en". Berdasarkan hasil observasi kepada AR diperoleh data bahwa kemampuan bicara masih berada dalam tahapan babbling. AR hanya mampu mengucapkan kata hmm..hmmm...hmmm.

Berdasarkan hasil wawancara dengan orangtua, AR pernah mengalami kejang saat usia 6 bulan. Sebelumnya perkembangan AR sama dengan anak pada umumnya tetapi setelah sakit perkembangan AR menjadi terhambat. Perkembangan bahasa AR sebelum sakit sudah memasuki tahap babling dimana ia mulai bisa mengucapkan pa..pa...pa atau huruf konsonan p, b, g. Tetapi perkembangan tersebut terhenti dan mundur setelah AR sakit sehingga perkembangannya masih terbatas pada penyuaraan refleks. Hasil tes Berra menunjukkan bahwa AR sama sekali tidak mengalami dalam gangguan pendengaran, bahkan ia mampu mendengarkan suara terkecil.

Kondisi objektif anak diperoleh dari hasil wawancara dan observasi. Data tersebut digunakan untuk menyusun program terapi wicara melalui pendekatan floor time yang disesuaikan dengan kebutuhan anak. Menurut Greenspan (2006) floor time, merupakan suatu cara sistematis bekerja dengan anak untuk membantunya melalui tahapan perkembangan, dengan harapan dapat membentuk emosi yang sehat, sosial dan intelektual

Hasil pelaksanaan terapi wicara melalui pendekatan floor time menunjukkan beberapa hasil yaitu: Tahapan 1 yaitu mengatur diri dan minat terhadap lingkungan. Hal pertama yang dilakukan yaitu mengamati tingkah laku anak terhadap lingkungan sekitarnya. Selanjutnya baru membuka lingkaran komunikasi. Tahapan ini AR dikenalkan pada lingkungan sekitarnya, hal ini juga dilakukan untuk menemukan minat AR. Pertemuan pertama sampai pertemuan ketiga AR masih sering menangis karena anak masih belum bisa beradaptasi dengan lingkungan. Pada pertemuan keempat anak sudah mulai merasa tenang dan intensitas menangis berkurang. AR mulai bisa memfokuskan pandangan selama tiga detik. Tahapan 2 yaitu Keakraban - keintiman.Tahap ini AR mulai dilatih dasar-dasar terapi wicara yaitu melalui proses pernafasan, makan, dan minum. Pertama, dilakukan pemijatan didaerah sekitar mulut dengan gerakan melingkar. Kemudian melatih anak untuk minum langkah-langkahnya adalah : Gunakan gelas plastik yang lebar, taruh bibir gelas di atas bibir bawah dan tutup bibir atas.Biarkan air mengalir ke mulut.Biarkan anak mengambil air dari gelas kemudian pegang rahangnya untuk menutup dan beri stimulus untuk menelan 
dengan gerakan memutar di bawah dagu. AR pada awalnya masih menggigit gelas karena masih terbiasa dengan menghisap dot.

Kemudian lama kelamaan AR mulai bisa memegang gelas sendiri meskipun air masih banyak yang tumpah. Ini menandakan bahwa kemampuan AR dalam menelan sudah mulai baik. Setelah itu AR mendapatkan terapi dasar makan. Langkah-langkahnya adalah : Menaruh makanan di tengah sendok teh. Tekan ke bawah kuat-kuat di atas lidah bagian bawah. Tunggu sampai rahang dan bibir menutup kemudian dengan pelan-pelan sentuh sendok itu untuk membiarkan makanan pindah ke mulut dengan bibirnya.Rahang dan bibir ditutup erat-erat dengan jari. Bantu gerakan mengunyah dan merangsang gerakan berputar di bawah dagu. AR mulai bisa memegang sendok sendiri dan mengunyah makanan dengan baik. Setelah proses makan diulang berkali-kali AR mulai merespon dengan mengambil sendoknya sendiri kemudian diberikan kepada peneliti.

Dalam tahapan kedua selain mengajarkan dasar terapi makan dan minum juga ada proses pemijatan. Dimana proses pemijatan dan pelemasan organ bicara disesuaikan dengan kondisi AR. Pertama proses pemijatan dilakukan dengan gerakan melingkar dimulai dari pipi, bibir atas, dan rahang bagian bawah. Sedangkan pelemasan organ bicara mengunakan sikat bayi yang diolesi dengan madu. Sikat dimasukkan kedalam mulut dimulai dengan mengosok-gosokan pada langit-langit mulut bagian atas, dilanjutkan ke pipi kanan dan kiri. Pada proses pertama dan kedua AR masih histeris tapi pada pertemuan selanjutnya AR sudah mulai terbiasa. Tujuan dari terapi ini untuk membantu melemaskan organ-organ bicaranya. Selama proses terapi dasar terapi wicara AR terus menerus diajak berbicara agar anak mendapatkan stimulus. Selain itu perlu merespon segala tingkah laku maupun emosi AR. Setelah dilakukan terapi dasar makan dan minum maupun pemijatan AR mulai merespon ketika namanya dipanggil dan menanggapi dengan senyuman.

Menanggapi uluran tangan, celoteh. AR menunjukkan emosi apabila dia tidak di respon atau ditanggapi sedikitnya 60 detik. Tahapan 3 yaitu komunikasi dua arah. AR mulai menanggapi isyarat dengan gerak-isyarat yang bertujuan misalnya meraih uluran tangan, membalas celoteh atau tatapan mata. AR mulai menunjukkan emosi seperti menjulurkan tangan meminta untuk digendong, membalas ketika dipeluk. Ketika ada suara musik atau lagu AR merespon dengan tertawa dan berjoget. AR mulai ketakutan ketika di tinggal mamanya pergi keluar. Ia mulai mengeluarkan suara "ma...ma...ma", lama kelamaan kosa katanya bertambah menjadi "Mama mana" meskipun pengucapannya masih belum jelas. Tahapan 4 yaitu menetapkan komunikasi kompleks. Dalam tahapan ini AR semakin jelas dalam menujukkan emosi dan komunikasinya. Ketika mama menjemput AR, ia berteriak-teriak dan tertawa riang sambil mengulurkan tangan minta digendong. Ketika menginginkan sesuatu ia mulai menggandeng tangan 
peneliti dan mengarahkan pada benda yang diminta. Tahapan 5 yaitu Ide Emosional.

Kemampuan AR dalam pendekatan floor time masih terhenti pada tahap komunikasi komunikasi kompleks atau tahapan yang ke-empat. Pendekatan floor time selain diterapkan di laboratorium PLB, peneliti juga memberikan pengarahan kepada orang tua agar menjalankan terapi yang sudah dilaksanakan untuk diulang lagi di rumah agar menunjukkan hasil yang optimal.

\section{SIMPULAN}

Berdasarkan hasil dan pembahasan penelitian mengenai pendekatan floor time diperoleh bahwa AR mengalami keterlambatan bicara. Perkembangan bicara AR kembali lagi pada tahapan babling. Hal ini terbukti dari kondisi bicara AR mampu menyuarakan hmmm.hmm.hmm. AR dalam meyuarakan keinginan dan emosinya dengan menangis. Sehingga untuk mengatasi hal tersebut disusunlah program terapi wicara melalui pendekatan floor time. Pendekatan floor time dilakukan dalam lima tahapan dan disesuaikan dengan kebutuhan AR. Setelah dilakukan pendekatan floor time AR mampu melaksanakan dalam empat tahapan. Hasil dari pelaksanaan pendekatan floor time menunjukkan bahwa AR mulai mampu merespon panggilan, bisa merabam, mengucapkan ma...ma...ma..., selain itu AR juga mampu mengucapkan 2-4 kosa kata. Ini membuktikkan bahwa dengan pendekatan floor time bisa membantu AR dalam meningkatkan perkembangan bicaranya.

\section{DAFTAR PUSTAKA}

Al-Gozali, S. (2011). Hambatan dalam Perkembangan Fisik. (Online). Tersedia: http://saidahalgazali.blogspot.com/2011/02/hambatan-dalamperkembangan-fisik.html diakses tanggal 02 Juni 2017.

Astuti, P.,P. (2013). Efektivitas Metode Bermain Peran (Role Play) untuk Meningkatkan Keterampilan Komunikasi Pada Anak. Jurnal Pendidikan Anak Usia Dini, 2 (1).

Creswell, J. (2012). Educational Research: Planning, Conducting, and Evaluating Quantitative and Qualitative Research. Boston: Pearson.

Greenspan, S.T \& Wieder, S. (2006). The Child with Special Needs (Anak BerkebutuhanKhusus. Jakarta: Penerbit Yayasan Ayo Main.

Hurlock, E.B (2002). Psikologi Perkembangan: 5th Edition. Jakarta: Erlangga.

Santrock, J.,W. (2007). Perkembangan Anak (Jilid 1). Jakarta: Erlangga. 